\title{
Laudato Si' - Socioeconomic Relevance for a Dynamic, Shifting, and Challenging Future
}

\author{
RiChaRd PAVLIĆ* - BRUNO RUKAVINA** \\ - https://doi.org/10.31823/d.29.2.3 • \\ UDK: 504:2*316.334.2 - Original Scientific Paper \\ Received: $8^{\text {th }}$ October 2020 • Accepted: $27^{\text {th }}$ May 2021
}

* Asst. Prof. Richard Pavlić, Ph. D., Catholic

Faculty of Theology, University of Zagreb, Theology in Rijeka, Omladinska 14, 51000 Rijeka, Croatia, ripavlic@gmail.com

** Bruno Rukavina, M. Pol. Sc., Croatia, bruno.rukavina. fpzg@gmail.com

Summary: The paper deals with the relevance of Laudato Si', five years after its publication. Given the Covid-19 crisis, which triggered the new economic crisis in the world, we believe that Laudato Si' is more relevant in 2020 than it was in 2015. The paper analyzes three socioeconomic segments of Laudato Si' to present its relevance today: mankind and our relationship with others, God and environment, the new economic crisis, and needed global action to comprehend and overcome the Covid-19 crisis. The processes and dangers of five years ago have not disappeared, they have only changed form. Thus, Laudato $\mathrm{Si}$ ' is not only relevant but can be used as a socioeconomic reconstruction program for Covid-19 aftermaths.

Keywords: Pope Francis, Laudato Si', Covid-19 crisis, Coronavirus, lockdown, economic system, economic crisis, technology, anthropocentrism.

\section{Introduction}

The Covid-19 crisis or Corona crisis has shown us that the world is in great need of a change in spheres of economy, politics, social interactions between humans and their relationship with nature and God. The world has become a less safe place and the new challenge for humanity does not discriminate between races, religions, cultures, rich or poor, those in power and those without it. This threat is one of the greatest in the last 100 years and the disappearance of the Spanish Flu. Unlike the 1918/20 pandemic, when most deaths occurred among healthy young adults 
(Taubenberger 91-92), coronavirus is more deadly to elderly people and people with pre-existing diseases (WHO, Situation Report 46). Every global challenge is also an opportunity to make something better after the threat. The same implies for the current Covid-19 crisis. Humanity should think about new ideas to rebuild the world to be safer and better once the danger of coronavirus is over. Laudato Si' of the Holy Father Francis on Care for our Common Home could be a virtuous program for the future.

In 2015, when the greatest challenges were climate change and terrorism, $\gg$ for the first time, the Pope dedicated a document to the complex relationship between poverty and environmental destruction and their significance for the future of humanity« (Ansorge 383). That document is not only thorough but also holistic, meaning that we should not only observe and study individual processes and events as separate from the whole and bigger picture of the world. ${ }^{1}$ Thus, Laudato $\mathrm{Si}^{\prime}$ is an excellent example of a comprehensive post-Covid-19 program for the world's future for better and sustainable life. This year marks the Special Anniversary Year (24 May 2020 - 24 May 2021) of Laudato Si', which makes this paper even more relevant (Dicastery for Promoting Integral Human Development). During the Covid-19 crisis, people of the world finally started to realize and understand that they need to change their way of life for a better tomorrow.

A research question of the paper is: How relevant is the document Laudato Si' in the 2020s, during and after the Covid-19 crisis?

We have been warned in the document by Pope Francis that there are dangerous processes in the world that have the potential of being lethal for mankind. The main thesis of the paper is that the Laudato Si' is now more relevant than five years ago and that we still have time to change our behavior so that both the Earth's nature and humanity can survive. Laudato $\mathrm{Si}^{\prime}$ is focused on humanity, ecology and spirituality and how they are influenced by different processes in economy, politics, sociology, technology and theology. We can consider the document as a roof that is based on five pillars; humanity, ecology and spirituality are the roof which is set on processes inside the pillars of economy, politics, sociology, technology and theology.

This paper will be based on a multidisciplinary approach, a scientific approach in which different disciplines deal with the same topic from their own specific perspectives and methods. These disciplines include economics, theology, sociology, political science, security studies, ecology, and criminology. The paper has three main parts through which we try to prove the relevance of Laudato Si'. The first part

\footnotetext{
${ }^{1}$ See Jan Christian Smuts, Holism and Holism and Evolution.
} 
will analyze mankind without the moral component and influence of the Coronavirus. How did we break relationships with our neighbors, nature, and God? What are the threats to mankind besides the virus? The second part of the paper will talk about critiques of neoliberal economic models and how to improve them. What is development and is there more to it than the accumulation of economic power (Pope Francis, Laudato Si' 105)? What suggestions can Laudato Si' recommend to overcome the economic crisis? The third part of the paper will discuss the importance of wide global action that is needed to fight, handle and overcome the Covid-19 crisis.

In the Croatian academic community, this topic is mostly covered by papers in theological-philosophical journals such as Diacovensia, Synthesis philosophica, Crkva $u$ svijetu, and Bogoslovska smotra. There are few articles in the Croatian language about Laudato Si' and the economy, like Ivan Platovnjak The Role of (Christian) Spirituality in the Economy in the Light of Laudato Si', and Stjepan Radić Laudato Si' and Justice. An Attempt at Drafting a Socio-Environmental Distribution of Goods. Most of the articles in Croatian are about ecology or agriculture and Laudato Si', like Đurica Pardon Biblical Theology of the Land - The Weft of the Encyclical Laudato Si', Danijel Jug Agriculture - A Stakeholder in the Causality of Climate Change, and Silvija Migles Preserving Climate through Dialogue. For this reason, in argumentation, we will mostly use literature in the English language.

The research is based on a linear model of research design that includes theoretical specification and formulation of hypotheses, specification of data, and their publication (Burnham 39). In addition, the paper will try to make a long-term comparative analysis of processes and phenomena before and after the outbreak of the epidemic crisis in order to see the difference in certain behaviors and case studies important for argumentation and causal relation. The methodology of the paper is based on analytical research and interpretation of literature that includes books, articles, official briefs, reviews, and reports available in Croatian and English.

The paper could have limitations, like a short period of analysis and research. For this reason, some future studies of socioeconomic effects that the Covid-19 crisis may cause in a long period of time could reveal different results and arguments. Furthermore, in the future, the Covid-19 crisis may affect different zones and areas of the world and mankind that we did not include in this research.

\section{Challenges to Mankind and the Covid-19 crisis}

The papal encyclical repeatedly states that mankind is presently under many negative influences and most of them have not changed in the last five years. Today's man is driven by wastefulness (LS 6) and vain consumerism $\gg$ which gives priority 
to short-term gain and private interest $\ll$ (LS 56), rather than long-term sustainable goals. $\gg$ Such a way of life is accompanied by constant, rapid and unsystematic changes (...), and the goals of this rapid change are not necessarily focused on the common good or on integral and sustainable human development « (LS 18). $\gg$ Change is something desirable, but it still becomes a source of anxiety when it harms the world and the quality of life « (LS 18). Generally speaking, changes should be gradual, so that people do not feel the change has taken place. The gradual approach prevents any resistance or aversion to a particular change. Due to the global pandemic situation, we had to, in a short period of time (approximately in several months), change our mindset to the $\gg$ new normal $\ll$, a term that emerged in the spring of 2020 in the WHO's documents about measures and guidelines for behavior during the Covid-19 crisis (Situation Report 94). That sudden change of the $\gg$ new normal « will be manifested in a broad social context, such as working from home and social distancing, but it will have consequences like increasing levels of different fear and anxiety and new job policies concerning health measures (Takieddine and Tabbah 15-16). ${ }^{2}$ Pope Francis emphasizes this as a problem of $\gg$ rapidification $\ll$, rapid changes which we cannot follow that leave us with negative consequences and the impossibility of healthy development (LS 18).

Worldwide quarantine at the beginning of 2020 could show itself to be a crucial event during which people reflected on how to reorganize their lives. We could see that constant change and a sense of false improvement are not worth much if we cannot go outside in nature or visit our friends and family. In Laudato Si' those are two out of $\gg$ three fundamental and closely intertwined relationships: with God, with our neighbor and with the earth itself $\ll(66)$ and $\gg$ according to the Bible, these three vital relationships have been broken, both outwardly and within us « (66). Interestingly, some of those relationships that are broken could be amended due to the Corona crisis consequences.

Firstly, our relationship with God decreased a great deal in the last decade. In 2018, Pew Research Center has proven that young adults tend to be less religious than their elders over the world. $\gg$ Although the age gap in religious commitment, (...) occurs in many different economic and social contexts - in developing states as well as advanced industrial economies, in Muslim-majority nations as well as predominantly Christian states, and in societies that are, overall, highly religious as well as those that are comparatively secular $\ll$ (Pew Research Center 5). National Geographic came across similar results while researching new trends in religion. $\gg$ The religiously unaffiliated are the second largest religious group in North America and most of Europe « (Bullard). In the last decade with increased numbers of

\footnotetext{
${ }^{2}$ Fear of losing a workplace, fear of others, fear of infection (germaphobe), etc.
} 
nonbelievers or less religious persons, the human relationship with God has been deteriorating. Therefore, Jeanet Sinding Bentzen found out, using new big data analysis and daily data on Google searches, that $\gg$ in March 2020, Google searches for prayer rose to the highest level ever recorded $\ll(21)$. $\gg$ People show an increased interest in prayer on the internet on all continents and for all religious denominations (...) in total, more than half of the world population have prayed to end the coronavirus « (Sinding Bentzen 21). The Corona crisis has shown us that we can rebuild and amend our relationship with God. Although research has shown that economic hardships and crises increase religiosity, and that increasing socio-economic security reduces the level of religiosity, this does not mean that the Church should take a passive stance and just wait for believers to come (Chen 300-354; Zuckerman 17-128; Paldam and Gundlach 1-30; Inglehart and Norris 3-196). The Church in times of evident re-spiritualization needs to be more active and open for new believers or re-spiritualized persons. In this way, it would be possible for the current increase in spirituality to become long lasting. What about the human relationship with other people?

If we look at several studies of crime rates over the world, there is a sense that the last two decades have shown a decrease in violence on the world level. The European Institute for Crime Prevention and Control has detected a declining tendency of homicide rates in the world, but in some parts of the world, there is an increase of violence like in parts of Africa and Latin America (Harrendorf et al. 7-21). »Countries in Central Asia, Eastern Europe and Western Europe show consistent decreasing trends over the time period « (Harrendorf et al. 17). A similar conclusion was published last year by Mateus Renno Santos and Alexander Testa. »Between 1990 and 2015, in both North America and Western Europe, the number of homicide victims per 100000 people declined by $46 \%$, while Asia saw a reduction of $38 \%$ and Oceania of $22 \%$ « (Santos and Testa). Furthermore, according to Eurostat, robberies in the EU fell by $34 \%$ between 2012 and 2018 and intentional homicides had a 30\% decline between 2008 and 2018 (Eurostat).

However, these data can be misleading. Will Koehrsen explained how statistics is the main problem with the decline of global violence. If we take an imaginary situation of two men fighting and one pulls a gun and shoots the other, the world crime rate in that bar would increase by $50 \%$ and if there is a civil war in a state of one million inhabitants and there are 10000 victims, the rate is 1\% (Koehrsen). $\gg$ Focusing on rates rather than numbers, we are neglecting the actual human suffering « (the numbers can be used to support multiple conclusions depending on one's argument) (Koehrsen). Nevertheless, there is a reason for optimism due to decreasing rates of deaths in armed conflicts, no battles between major powers since 1953, and a reduction in overall battle deaths since the 1950s (Koehrsen), but 
we are a long way from the Laudato Si"s vision of the world since there were many wars and conflicts after the 1950s. »This is a far cry from our situation today, where sin is manifest in all its destructive power in wars, the various forms of violence and abuse, the abandonment of the most vulnerable, and attacks on nature $\ll$ (LS 66). How has the Covid-19 crisis affected the violence in the world?

There is still not much research and data concerning violence and crime rate during the Covid-19 crisis. Nonetheless, several think tanks and academic researchers do have some insights. One of them is Terry Goldsworthy, who noticed that $\gg$ certain crimes, such as robberies and sexual offences, have declined dramatically, while others, such as online fraud, have been on the rise « and $\gg$ offences that could be committed in private settings or remotely, such as cybercrimes, rose dramatically during the pandemic « (Goldsworthy). Similar acknowledgments were published in several papers by Global Initiative. ${ }^{3}$ Lockdowns and social distancing have influenced and decreased violent street crimes, homicides, robberies, grand theft, and mafia-related murders (Global Initiative 4-8). The crisis is also decreasing human trafficking and illegal smuggling of migrants (Wagner and Hoang 1-8).

On the other hand, cybercrimes have increased as people move their work in lockdown and new main objects of hackers became hospital and pharmaceutical companies (Mahadevan 1-15). »Cybercrime is on the rise as many turn to the internet as their primary link to the world « (Walker 3 ). To conclude, routine activity theory in criminology (NSW Government), perfectly explains this situation of criminal replacement. The theory is based on the triangle $\gg$ Offender-Place-Victim $\ll$ and if certain places of crimes are no longer available, the offenders will find the place where they can harm victims and nowadays this is in cyberspace. The same theory is valid for domestic violence since there was an increased level of it, worldwide according to UN committees (UN, »The COVID-19 shadow pandemic «1-5). In Laudato $\mathrm{Si}^{\prime}$, there is special about $\gg$ primary social group, family $\ll(142)$, since it is $\gg$ the basic cell of society « (157). Degradation of the family is a long-lasting process, and some argue that it came about with changes in the economic sphere since individual satisfaction is valued more than family. Liberal individualism is blooming to the detriment of family solidarity. Modern societies are failing to create mothers and fathers due to values which emphasize the freedom of choice over family obligations and responsibilities (Thurow 31-33). Increased domestic violence is a dangerous threat since family is $\gg$ the place in which life - the gift of God - can be properly welcomed and protected against the many attacks to which it

\footnotetext{
${ }^{3}$ Since Global Initiative policy briefs have warnings about transmitting and reproducing their publications, the authors contacted the Secretariat of Global Initiative and got permission to use their briefs for this research.
} 
is exposed $\ll$ (LS 213). Sinful behavior which devastates families could be looked upon with virus analogy, it enters one cell (family), multiplies in it, then through time spreads to other cells until the whole organism (local/nation/international community) is infected (LS 142).

The third relationship that has been broken is one between mankind and nature. It is obvious that climate change is a reality in which we live (Wang and Chameides 3-5). This is clearly stated in Laudato Si' and it is the central point of the papal encyclical since $\gg$ climate change is a global problem with grave implications: environmental, social, economic, political and for the distribution of goods « (LS 25 ). Furthermore, there is an increased risk of extinction of many species of flora and fauna. The space inhabited by many animals is decreasing, and the areas that threaten biodiversity are geographically increasing (Pimm 3-7). In 2019 and 2020 fires all over the world, the largest being in Siberia, Amazon and Australia, burned ecosystems that do not usually burn and almost made some species extinct (Wood and Ventimiglia, $\gg$ Global Fires $\ll$ ). $\gg$ Each year sees the disappearance of thousands of plant and animal species which we will never know, which our children will never see, because they have been lost forever « (LS 33). Different species are not just usable $\gg$ resources $\ll$, but they have value in the larger ecosystem. $\gg$ All creatures are connected, each must be cherished with love and respect, for all of us as living creatures are dependent on one another $\ll$ (LS 42).

During the Covid-19 crisis we started to understand human impact on ecology and nature. Worldwide lockdowns have $\gg$ resulted in some short-term environmental improvements, including significant reductions in local air-pollution and greenhouse gas emissions in many countries (particularly in urban areas) « (OECD, From containment to recovery). $\gg$ Large-scale and extensive restrictions in mobility $(. ..) \ll$ (Cheval et al. 7) and $\gg$ strong decrease in both short-term and mid-term aviation travel, will lead to a reduction in greenhouse gas emissions, particularly $\mathrm{CO} 2 \ll(8)$. »Additionally, the reduction in contrails may increase the daily temperature range and the reduction of contrails will probably lead to a decrease in air temperature due to the decreasing greenhouse effect $\ll$ (Cheval et al. 8). This proves how mankind has a great influence on nature. We need to become the change we want to see in the world and Pope Francis clearly states how $\gg$ there can be no ecology without an adequate anthropology $\ll$ (LS 118).

The key cause for mankind's breaking relationship with nature and God is anthropocentrism. According to the Cambridge Dictionary, anthropocentrism is an ideology or doctrine which considers $\gg$ humans and their existence as the most important and central fact in the universe « (Cambridge Dictionary). Encyclopedia Britannica explains that anthropocentrism $\gg$ regards humans as separate from and 
superior to nature and holds that human life has intrinsic value while other entities (including animals, plants, mineral resources) are resources that may justifiably be exploited for the benefit of humankind « (Boslaugh). This is a misguided view of the world. »Each creature possesses its own particular goodness and perfection (...). Each of the various creatures, willed in its own being, reflects in its own way a ray of God's infinite wisdom and goodness. Man must therefore respect the particular goodness of every creature, to avoid any disordered use of things « (LS 69). One of the main postulates of Christian anthropology is the notion of man in his relational determination/ability that he inherits as a being created in the image of God (Pavlić and Kevrić 365-388).

Interestingly, anthropocentrism is not a new/modern doctrine. It can be looked upon as a revised ancient Greek argument from Sophists, especially teachings of Protagoras of Abdera. In the core of anthropocentrism, we can find his quote: $\gg$ Of all things the measure is man, of the things that are, that they are, and of the things that are not, that they are not $\ll$ or simply stated, $\gg$ man is the measure of all things $\ll$ (Mark). This has opened doors to relativism and $\gg$ some of the younger followers of Protagoras and the other older Sophists concluded that the arbitrary nature of human laws and customs implies that they can be ignored at will « (Poster). Relativism is part of Pope Francis' special warning, not only in Laudato Si' but in Apostolic Exhortation Evangelii Gaudium. He noticed that relativism is more dangerous in practice than in theory since $\gg$ it has to do with the deepest and inmost decisions that shape their way of life « (Apostolic Exhortation Evangelii Gaudium 80). »When human beings place themselves at the center $(\ldots)$ we should not be surprised to find, in conjunction with the omnipresent technocratic paradigm and the cult of unlimited human power, the rise of a relativism which sees everything as irrelevant unless it serves one's own immediate interests « (LS 122). These postulates of anthropocentrism and relativism can lead to dangerous processes such as biotechnological, genetic mutations and manipulations which can either improve life (LS 131-132) or make it more dangerous or even deadly to life on Earth. One of the theorized causes of the current crisis is that the Covid-19 virus arose based on laboratory biotechnological engineering, although we shall study the manner and causes of the pandemic for a long time (Menachery et al. 2015) (Ge et al. 2013). Nonetheless, $\gg$ a misguided anthropocentrism leads to a misguided lifestyle $\ll$ (LS 122).

Moreover, due to phenomena of anthropocentrism and relativism, there is a rise of technological dependency in society. »Modern anthropocentrism has paradoxically ended up prizing technical thought over reality« (115). Laudato $\mathrm{Si}^{\prime}$ is acknowledging the benefits of technological improvement, but the same improvement $\gg$ has remedied countless evils which used to harm and limit human beings $\ll$ 
(102). Technology as such is not a problem, since it can make life easier and better. The main issue is wrong perception and approach to technology that becomes the goal of human action and life, and not a means to improve and facilitate life (107108). The threat is even greater under the conditions of the Covid-19 crisis, where people are transferring education, sales, payments, banking, shopping, trade, and other aspects of life online in order to protect physical health (WTO, E-commerce, Trade and the Covid-19 Pandemic). It is important that we do not become dependent and lose ourselves in those necessary technological circumstances caused by a temporary pandemic. $\gg$ Life gradually becomes a surrender to situations conditioned by technology, itself viewed as the principal key to the meaning of existence $\ll$ (LS 110). However, »there is a growing awareness that scientific and technological progress cannot be equated with the progress of humanity and history, a growing sense that the way to a better future lies elsewhere « (LS 113). After this crisis, we shall see if the awareness is increased or decreased.

\section{New Economical Doctrine}

Following the technological argument, the economic system $\gg$ accepts every advance in technology with a view to profit, without concern for its potentially negative impact on human beings « (LS 109). The Covid-19 crisis has in some measure facilitated the struggle against negative habits which undermine nowadays societies, states, the human spirit, and the environment. $\gg$ Many people know that our current progress and the mere amassing of things and pleasures are not enough to give meaning and joy to the human heart, yet they feel unable to give up what the market sets before them « (LS 209). However, Post-Cold War common behavior of tireless buying of often unnecessary products started to slowly change. $\gg$ Buying more and more things as a source of identity and meaning seems to be gradually but consistently falling out of favor « (Canavan). A similar conclusion was identified in the analysis of the Global Development and Environment Institute (Roach et al. 5-41). There are two reasons which will change the consumerist lifestyle: insufficient consumption (poverty) and new non-consumerist values (Roach et al. 16-18). This is an important change in consumer behavior since $\gg$ obsession with a consumerist lifestyle, above all when few people are capable of maintaining it, can only lead to violence and mutual destruction « (LS 204). Decrease of consumerism is expected in the future due to the Covid-19 crisis: »consumers have shifted to more mindful shopping, (...) and are more mindful of their spending and trading down and intend to shift their spending largely to essentials, such as grocery and household supplies, and 
cut back on discretionary categories « (Arora et al. 4). ${ }^{4}$ According to Manitoba Analytics, $\gg$ consumer product sector revenue is expected to decline by $\$ 359.9$ billion (3.9 per cent) in 2020, compared to baseline predictions $\ll(2)$. $\gg$ Thus, concerns around physical health connected to COVID-19 and economic hardship related to lay-offs and job insecurity will continue to affect consumers shopping behavior and willingness to spend « (Manitoba Analytics 2). To conclude, this difficult situation in the long-term could lead to less consumeristic, egoistic and individualistic society so that in the future we can $\gg$ opt for a non-consumerist model of life, recreation and community $\ll$ (LS 112).

Economic crises should make us reevaluate economic development and growth, which is base for neoliberal capitalism. Laudato Si' stresses this false $\gg$ tendency to believe that every increase in power means an increase of progress itself, an advance in security, usefulness, welfare and vigor; (...) an assimilation of new values into the stream of culture, $(\ldots)$ as if reality, goodness and truth automatically flow from technological and economic power as such $\ll(105)$. On the contrary, the supporting accumulation of power is increasing wealth differences, the gap between rich and poor and in the framework of cultural relativism and anthropocentrism, $\gg$ drives one person to take advantage of another, to treat others as mere objects, imposing forced labor on them or enslaving them to pay their debts $<$ (LS 123). »The principle of the maximization of profits, frequently isolated from other considerations, reflects a misunderstanding of the very concept of the economy (LS 195).

Such economic and political processes are not easy to change or reform. William Easterly in his book The Elusive Quest for Growth decided to go on a daring research, to find out how poor states in the tropics can become rich like those in Europe and North America. Economists thought they could find an elixir that would allow them to enrich those states, such as aid, investing in machinery, fostering education, controlling demographic trends, lending to conditional reforms, granting debt forgiveness to conditional reforms. However, nothing helped. Poor states have not experienced growth. Interestingly, it was not a failure of economics, but a failure to apply economic principles to practical work (Easterly 1-5). It is important to emphasize that when the author talks about growth, he means an increase in living standards, i.e., development. A way to achieve this is to increase the production of goods, i.e., production per worker, which is also called labor productivity and with technological change. However, there could be problems because one worker will be in charge of more machines, and nothing good will happen if we add another

\footnotetext{
${ }^{4}$ Discretionary spending - money spent by consumers on things other than necessary things such as food, clothes, and fuel, Cambridge dictionary, https://dictionary.cambridge.org/dictionary/english/discretionary-spending. Accessed 24 Aug. 2020.
} 
worker who controls nine machines. The conclusion was that increasing one ingredient while the other ingredient remains unchanged will not allow us to achieve the desired growth (Easterly 47-57).

After the Cold War, the dominant socioeconomic process which has taken place was $\gg$ the enormous and continuing acceleration of the ability of the human species to change the planet by means of technology and economic activity, and globalization $\ll($ Hobsbawm 2). Mass technologization and constant growth of production do not lead to prosperity and development of states. $\gg$ We fail to see the deepest roots of our present failures, which have to do with the direction, goals, meaning and social implications of technological and economic growth « (LS 109). Many measures to enrich poor states have failed: loans, the unsuccessful fight against corruption, huge donations. Moreover, technological development occurs for non-economic reasons, like scientific development (Easterly 52). Therefore, priority should be a change of the political system and its attitude to the economy. >Modern economic growth and development are accompanied by a set of sweeping structural changes and transformations « (Acemoglu 861). »These include changes in the composition of production and consumption, urbanization, financial development, changes in inequality of income and inequality of opportunity, the transformation of social and living arrangements, changes in the internal organization of firms, and the demographic transition « (Acemoglu 861). If the changes are based without having in mind the larger picture of sustainable development $>$ people's quality of life actually diminishes - by the deterioration of the environment, the low quality of food or the depletion of resources - in the midst of economic growth « (LS 194). The process of economic transformation is complex, multilayered, and it cannot be achieved without a comprehensive change of society. Irrelevant are $\gg . .$. the most extraordinary scientific advances, the most amazing technical abilities, the most astonishing economic growth, unless they are accompanied by authentic social and moral progress « (LS 4). »A technological and economic development which does not leave in its wake a better world and an integrally higher quality of life cannot be considered progress « (LS 194). Can we expect change due to the current economic crisis and recession caused by the global lockdown and what can we expect?

The crisis which began with external factors does not subside easily, since the waves of negative impacts are slowly normalizing in the economy (Pavlek Posavec). The negative factor of this crisis, compared to the one from 2008, is the present higher debt in the world: »Since the absolute levels of debt are significantly higher and the debt ratios are higher than in 2007 , with a significantly lower quality of debt (lower average rating), we can expect a more serious decline than in $2008 \ll$ (Pavlek Posavec). When the pandemic started many governments started implementing 
policies to preserve public health. They have a long-term influence on the economy, especially lockdowns since $\gg$ a 30-day social distancing policy or lockdown restriction hurts the economy through a reduction in the level of general economic activities and through its negative effect on stock prices « (Peterson 24). However, some states decided to prolong lockdown and social distancing, further deepening the economic crisis. $\gg$ As often occurs in periods of deep crisis which require bold decisions, we are tempted to think that what is happening is not entirely clear « (LS 59). Thus,

$>$ there were criticisms that the policies were too fast, premature or insufficient, and that the policies contradicted one another in some areas, for instance, the accommodative monetary policy encouraged economic agents to engage in economic activities while the lockdowns and social-distancing (stay-at-home) policy prevented economic activities from taking place $\ll$ (Peterson 24$)$.

According to the International Monetary Fund, $\gg$ many countries face a multi-layered crisis comprising a health shock, domestic economic disruptions, plummeting external demand, and capital flow reversals « (IMF 157). When the pandemic started there were two methods of dealing with critical situations: The Hammer and the Dance (radical restrictions with gradual subsequent relaxations) (Šonje). In the summer of 2020, several states decided to start with the Dance due to economic benefits and profits. The consequences of the Dance are yet to be seen. Even if a vaccine is discovered, the health crisis and excessive restrictions implemented so far will have a negative influence on the larger social-political-economic situation, such as

>declining incomes, unemployment, mental disorders that can range from mild anxiety to severe depression, a propensity to drink and consume stronger opiates, eating disorders, (...) interruption or weakening of all forms of education, a sense of hopelessness - loss of optimism and hope, loneliness, stress, affirmation of conspiracy theories and support for solid solutions $\ll$ (Šonje).

Laudato $\mathrm{Si}^{\prime}$ has detected the need for systematic economic and development change, especially after the economic crisis from 2008. $\gg$ The financial crisis of 2007-08 provided an opportunity to develop a new economy, more attentive to ethical principles, and new ways of regulating speculative financial practices and virtual wealth « (LS 189). Instead of looking for the reasons, we should work on the transformation of the economy to ensure that the next crisis that comes, does not significantly affect people's lives. $\gg$ The lessons of the global financial crisis have not been assimilated « (LS 109). Ivan Platovnjak argued that spirituality needs to 
play an important role in the economy in order to transform it, which is one of the main suggestions of Laudato Si' (73). »More and more people in the West are aware that modern economics offers virtual satisfaction and confirmation, but at a deeper level, the continual acquisition of goods and the search for profit does not satisfy the hunger of their spirits « (Platovnjak 75). »Contrary to the mindset of the prevailing secularized, materialistic, and consumer culture, it is precisely in spirituality that they have 'discovered' the lost or hidden dimension of their lives « (Platovnjak 75). Due to the Covid-19 crisis and the economic one that the first one caused, there is a rise in religion and spirituality all over the world. This growing spirituality could influence the economy. Besides, in present pandemic times, we need $\gg$ a more humane, compassionate, and the economy of solidarity $\ll$ (Platovnjak 79). A similar conclusion was made by Stjepan Radić, for justice and solidarity. $\gg$ Following in the footsteps of Catholic social doctrine and his predecessors (especially Pope John Paul II), Pope Francis constantly points out that all true justice must necessarily be in solidarity « (Radić 61). There is a need to develop economic institutions and social programs for the poor through principles of solidarity (61), especially during a crisis.

What Pope Francis is emphasizing is a call for global conversation and dialogue about a revaluation of not only the political but economic system. It has weak points because in the $21^{\text {st }}$ century the world governance is based on the $20^{\text {th }}$ century system and $\gg$ it is essential to devise stronger and more efficiently organized international institutions, with functionaries who are appointed fairly by agreement among national governments, and empowered to impose sanctions « (LS 175). Transformation of the system is needed, but through it, we need to transform ourselves. Ivan Platovnjak has pointed out an important conclusion: »Never should a human being serve the economy, the economy should always be in the service of humans and society by helping them to become more a human being of relationships, a gift for others, society, and the environment $\ll(83)$.

\section{Global Action and the Covid-19 crisis}

The most important problems while coping with the Covid-19 crisis, are lack of leadership and vague responsibilities to manage the crisis. Who can be a leader that conducts a fight against something as dangerous as coronavirus? An international organization that deals with diseases - the World Health Organization (WHO). ${ }^{5}$ According to the WHO Constitution, one of its main objectives is $\gg$ to establish and maintain such administrative and technical services as may be required, in-

${ }^{5}$ See about the World Health Organization: https://www.who.int/about/who-we-are/history. Accessed 27 Aug. 2020. 
cluding epidemiological and statistical services $\ll($ WHO, $\gg$ Constitution $\ll 2)$. Furthermore, if there is an emergency that requires immediate action the WHO $\gg$ may authorize the Director-General to take the necessary steps to combat epidemics « (WHO, $\gg$ Constitution « 9). Due to this, we could hear recommendations, briefings and advice from the WHO about the Covid-19 virus. When the crisis started in China, some information about the new virus was vague and imprecise since there was not much research carried out about the threat. Constantly updating and adjusting information, while heavily criticized, the WHO played the crucial role in the fight against the pandemic. Director-General Tedros Adhanom Ghebreyesus explained how the importance of the WHO is seen through: helping states to prepare and respond, providing accurate information, ensuring vital supplies reach frontline health workers, training health workers and the search for a vaccine (UN, $\gg 5$ reasons the world needs WHO, to fight the COVID-19 pandemic $\ll$ ). The WHO has a function of global technical assistance and work, but also a normative role as the only organization responsible for world health (Prah Ruger 3-4). To sum up, it is better to have such an organization that can coordinate and manage the epidemic crisis, than to leave crisis management only to nation states, without any international advisory and body for cooperation. $\gg$ Diplomacy also takes on new importance in the work of developing international strategies which can anticipate serious problems affecting us all $\ll$ (LS 175).

The fight against pandemic (and climate change) cannot be guided by either a »bottom-up « or a »top-down « approach. This struggle must be waged simultaneously from both above and below, promoting the inclusiveness of all actors. The reason for this is very simple, the Covid-19 crisis is a great global problem with serious consequences: social, economic and political (LS 25). »In Covid-19 context one can think on four levels: on the individual level, on local community level, on national level, and at the global level « (Jakovljevic et al. 6-14). Joint action needs to be multilevel, inclusive at all vertical levels and encompassing the breadth and diversity of actors. The local level is very important, so in the future, measures and rules about the pandemics should be locally oriented in order to preserve health, but also to save other aspects of life (like the economy). »While the existing world order proves powerless to assume its responsibilities, local individuals and groups can make a real difference « (LS 179). »A local approach to the assessment of risk is important, taking into consideration the epidemiological situation, local services and information on the impact of previous measures implemented $\ll$ (European Centre for disease, prevention and control 14). The local levels of governance will be an important part of activities and lessons that might emerge after the pandemic. $\gg$ Political activity on the local level could also be directed to modifying consumption, developing an economy of waste disposal and recycling « (LS 180). 
The current crisis should not be exploited to weaken states or violate their sovereignty, especially from large private multinational and transnational organizations which could exploit a pandemic crisis for their own interest. »We cannot overlook the huge global economic interests which, (...) can undermine the sovereignty of individual nations « (LS 38). Furthermore, the crisis should not be used to impose and force upon others different ideas and behaviors in states with nonidentical social-economic surroundings and long-term legacy. $\gg$ There is a need to respect the rights of peoples and cultures, and to appreciate that the development of a social group presupposes a historical process which takes place within a cultural context and demands the constant and active involvement of local people from within their proper culture $\ll$ (LS 144). This is similar to the arguments of the international relations scientists who argue a need for multipolar world order. Next to the unipolar (world order from 1989 until the beginning of $21^{\text {st }}$ century - American primacy) (Brooks and Wohlforth 17) and bipolar (Cold War era), the multipolar world is the one in creation, due to the growing power and importance of China and Russia. In an ideological sense, it has authentical anti-dogmatic ideology whose main sets of values are based on advocacy for a broad spectrum of local and regional sociologic, cultural, political, and economic possibilities in contrast to uniformity, standardization, simplified and rationalized mankind (Dugin 38). In essence, this is what Laudato $\mathrm{Si}^{\prime}$ is trying to express as well: $\gg$ A consumerist vision of human beings, encouraged by the mechanisms of today's globalized economy, has a levelling effect on cultures, diminishing the immense variety which is the heritage of all humanity« (LS 144). Furthermore, »era of dramatically accelerated globalization is giving rise to regional disparities around the planet, for by its very nature globalization produces unbalanced and asymmetrical growth « (Hobsbawm 38). Thus, »new processes taking shape cannot always fit into frameworks imported from outside; they need to be based in the local culture itself $\ll$ (Hobsbawm 38).

Global action must not be unified action coming from one center which is imposed on others. It is actually a sum of coordinated actions across the world for a better and sustainable future while respecting everyone's differences. To fight against the Covid-19 and all the crises it has triggered, there cannot be one conclusive action against it, but a large aggregation of behavioral changes on different levels. Due to the interdependence and interaction of everyone on the planet, especially those involved in economics, politics and science, the necessary action for the future should be based on a holistic comprehensive approach (LS 164-165).

\section{Conclusion}

The Covid-19 crisis has changed the socioeconomic surroundings and made us rethink our values, behavior, and life in general. Due to it, we are starting to rebuild 
our relationship with God, since the present times of peril are increasing spirituality. We are realizing our influence and responsibility for climate changes and the devastation of nature. However, we still have a lot of work to do on our relationships with each other, since crime is still happening, it has only changed places, from streets into cyberspace and families during the worldwide lockdowns. Furthermore, this crisis has made us more dependent on technology which is a challenge for mankind if it is continually misused, especially in the world with ideas and practices of anthropocentrism and relativism. The current economic crisis, which is caused by a pandemic, will affect millions of people across the board. Therefore, Laudato Si' relevantly shows deficiencies in the neoliberal economic system and the need for global solidarity. The critiques of the economic system are not just empty words, but a call for action to improve the shortcomings and create a base for changes that will lead to a prosperous future. International cooperation based on holism, encompassing every realm, from religion, science, politics, economy, and business, is the main goal addressed in the Laudato Si'. In essence, it is a comprehensive, inclusive, universal, and cross-disciplinary document that preaches a broad social action to amend the negative habits of mankind, and as such, it can become a future program of socioeconomic reconstruction after the Covid- 19 crisis. 


\section{Works Cited}

Acemoglu, Daron. Introduction to Modern Economic Growth, New Jersey: Princeton University Press, 2009.

Arora, Nidhi, et al. $\gg$ A global view of how consumer behavior is changing amid COVID-19.« McKinsey \& Company, 2020, https://www.mckinsey.com/ /media/McKinsey/Business\%20Functions/Marketing\%20and\%20Sales/Our\%20Insights/A\%20 global\%20view\%20of\%20how\%20 consumer\%20behavior\%20is\%20changing\%20 amid\%20COVID\%2019/20200707/covid-19-global-consumer-sentiment-20200707. pdf. Accessed 24 Aug. 2020.

Ansorge, Dirk. »Božja nježnost u svim stvorenjima: temeljna misao enciklike pape Franje Laudato sì.« Filozofsko-teološka visoka škola Sankt Georgen, vol. 54, no. 3, 2019, pp. 383396.

Boslaugh, Sarah E. »Anthropocentrism «. Encyclopedia Britannica, https://www.britannica. com/topic/anthropocentrism. Accessed 23 Aug. 2020.

Brooks, Stephen, and William Wohlforth. World Out of Balance: International Relations and the Challenge of American Primacy, New Jersey: Princeton University Press, 2008.

Bullard, Gabe. »The World's Newest Major religion: No Religion.« National Geographic, 2016, https://www.nationalgeographic.com/news/2016/04/160422-atheism-agnostic-secular-nones-rising-religion/. Accessed 21 Aug. 2020.

Burnham, Peter (ed.). Metode istraživanja politike, Zagreb: Fakultet političkih znanosti, 2006.

Cambridge Dictionary, https://dictionary.cambridge.org/. Accessed 24 Aug. 2020.

Canavan, Brendan. $\gg$ Consumerism in crisis as millennials stay away from shops. $\ll$ The Conversation, 2019, https://theconversation.com/consumerism-in-crisis-as-millennialsstay-away-from-shops-109827. Accessed 24 Aug. 2020

Chen, Daniel. »Club Goods and Group Identity: Evidence from Islamic Resurgence during the Indonesian Financial Crisis.«Journal of Political Economy, vol. 118, no. 2, 2010, pp. 300-354.

Cheval, Sorin, et al., >Observed and Potential Impacts of the COVID-19 Pandemic on the Environment.« International Journal of Environmental Research and Public Health, vol. 17, no. 11, 2020, pp. 1-25.

Dicastery for Promoting Integral Human Development, »Laudato Si' - Special Anniversary Year 24 May 2020 - 24 May 2021.« 2020, http://www.humandevelopment.va/content/dam/sviluppoumano/documenti/ FINAL\%20EN\%20-\%20Laudato\%20si'\%20 Anniv\%20Year\%202020-2021.pdf. Accessed 4 Sept. 2020.

Dugin, Aleksandar. Geopolitika multipolarnog svijeta, Zagreb: Eneagram zadruga za izdavaštvo, 2012. 
Easterly, William. The Elusive Quest for Growth: Economists' Adventures and Misadventures in the Tropics, Massachusetts: The MIT Press, 2001.

European Centre for disease, prevention and control, >Coronavirus disease 2019 (COVID-19) in the EU/EEA and the UK - eleventh update: resurgence of cases. $\ll 2020$, https://www.ecdc.europa.eu/sites/default/files/documents/covid-19-rapid-risk-assessment-20200810.pdf. Accessed 28 Aug. 2020.

Eurostat, $\gg$ Crime statistic. « 2020, https://ec.europa.eu/eurostat/statistics-explained/index.php/Crime_statistics. Accessed 21 Aug. 2020.

$\mathrm{Ge}$, Xing-Yi, et al. »Isolation and characterization of a bat SARS-like coronavirus that uses the ACE2 receptor.« Nature, vol. 503, 2013, pp. 535-538.

Global Initiative, $\gg$ Crime and Contagion.«2020, https://globalinitiative.net/wp-content/ uploads/2020/03/GI-TOC-Crime-and-Contagion-The-impact-of-a-pandemic-on-organized-crime.pdf. Accessed 21 Aug. 2020.

Goldsworthy, Terry. »Some crimes have seen drastic decreases during coronavirus - but not homicides in the US.«The Conversation, 2020, https://theconversation.com/ some-crimes-have-seen-drastic-decreases-during-coronavirus-but-not-homicides-inthe-us-142718. Accessed 21 Aug. 2020.

Harrendorf, Stefan, et al. (ed.). »International Statistics on Crime and Justice.« European Institute for Crime Prevention and Control, 2010, https://www.unodc.org/documents/ data-and-analysis/Crime statistics/International_Statistics_on_Crime_and_Justice. pdf. Accessed 21 Aug. 2020.

Hobsbawm, Eric. Globalization, democracy and terrorism, London: Little Brown, 2007.

Inglehart, Ronald, and Pippa Norris. Sveto i svjetovno - Religija i politika u svijetu, Zagreb: Politička kultura, 2007.

International Monetary Fund (=IMF), »World Economic Outlook - The Great Lockdown. $\ll 2020$.

Jakovljevic, Miro, et al. >COVID-19 Pandemia and Public and Global Mental Health from the Perspective of Global Health Security.«Psychiatria Danubina, vol. 32, no. 1, 2020, pp. 6-14.

Koehrsen, Will. »Has Global Violence Declined? A Look at the Data.« Medium, 2019, https://towardsdatascience.com/has-global-violence-declined-a-look-at-the-data-5af708f47fba. Accessed 21 Aug. 2020.

Mahadevan, Prem. $\gg$ Cybercrime - Threats during the COVID-19 pandemic. $\ll$ Global Initiative, 2020, https://globalinitiative.net/wp-content/uploads/2020/04/Cybercrime-Threats-during-the-Covid-19-pandemic.pdf. Accessed 21 Aug. 2020.

Manitoba Analytics, »Impact of COVID-19 on Consumer Behavior.« 2020, https:// www.gov.mb.ca/agriculture/markets-and-statistics/economic-analysis/pubs/impact-of-covid-on-consumer-behaviour.pdf. Accessed 24 Aug. 2020. 
Mark, Joshua. »Protagoras of Abdera: Of All Things Man Is The Measure. « Ancient History Encyclopedia, 2012, https://www.ancient.eu/article/61/protagoras-of-abdera-of-allthings-man-is-the-meas/. Accessed 23 Aug. 2020.

Menachery, Vineet, et al. $\gg$ A SARS-like cluster of circulating bat coronaviruses shows potential for human emergence. $\ll$ Nature Medicine, vol. 21, 2015, pp. 1508-1513.

NSW Government, »Routine activity theory.« 2011, http://www.crimeprevention.nsw. gov.au/Documents/routine_activity_factsheet_nov2014.pdf. Accessed 21 Aug. 2020.

Organization for Economic Co-operation and Development (=OECD), »From containment to recovery: Environmental responses to the COVID-19 pandemic. $\ll 2020$, https://read. oecd-ilibrary.org/view/?ref=126_126460-1tg1r2aowf\&title=From-containment-to-recovery_Environmental-responses-to-the-COVID-19-pandemic. Accessed 22 Aug. 2020.

Paldam, Martin, and Erich Gundlach. »The religious transition: a long-run perspective.« Kiel Institute for the World Economy, 2009, https: / / www.files.ethz.ch/isn/111449/kwp1576.pdf. Accessed 21 Aug. 2020.

Pavlek Posavec, Stjepan. »Korona-kriza: bankroti tvrtki i financijska kriza.« Ekonomski lab, 2020, http://arhivanalitika.hr/blog/korona-kriza-bankroti-tvrtki-i-financijska-kriza/. Accessed 26 Aug. 2020.

Pavlić, Richard, and Katarina Kevrić. »Stvaranje čovjeka u svjetlu kršćanske antropologije i susreta s prirodnim znanostima.« Riječki teološki časopis, vol. 46, no. 2, 2015, pp. 365388.

Peterson, Ozili. »Spillover of COVID-19: impact on the Global Economy. « SSRN Electronic Journal, 2020, pp. 1-27.

Pew Research Center, $\gg$ The Age Gap in the Religion Around the World.« 2018, https:// www.pewforum.org/wp-content/uploads/sites/7/2018/06/ReligiousCommitment-FULL-WEB.pdf. Accessed 21 Aug. 2020.

Pimm, Stuart, et al. »The biodiversity of species and their rates of extinction, distribution, and protection. $\ll$ Science, vol. 344, 2014.

Platovnjak, Ivan. »The Role of (Christian) Spirituality in the Economy in the Light of Laudato si'.« Synthesis philosophica, vol. 34, no. 1, 2019, pp. 73-86.

Pope Francis. $\gg$ Apostolic Exhortation Evangelii Gaudium of the Holy Father Francis to the bishops, clergy, consecrated persons and the lay faithful on proclamation of the Gospel in today's world.« The Holy See, 2013, http://www.vatican.va/content/francesco/en/ apost_exhortations/documents/papa-francesco_esortazione-ap_20131124_evangelii-gaudium.html. Accessed 23 Aug. 2020.

---. Encyclical Letter Laudato Si' of the Holy Father Francis on Care for our Common Home (=LS). Vatican: Vatican Press, 2015.

Poster, Carol. »Protagoras (fl. 5th c. B.C.E.).« Internet Encyclopedia of Philosophy, https:// iep.utm.edu/protagor/. Accessed 23 Aug. 2020. 
Prah Ruger, Jennifer. »The Global Role of the World Health Organization.« Global Health Governance, vol. 2, no. 2, 2009, pp. 1-11.

Radić, Stjepan. »Laudato si' i pravednost, Pokušaj nacrta jedne socijalno-ekološke raspodjele dobara.« Diacovensia, vol. 24, no. 1, 2016, pp. 45-64.

Roach, Brian, et al. »Consumption and the Consumer Society.« Global Development And Environment Institute, 2019, http://www.bu.edu/eci/files/2019/10/Consumption_ and_Consumer_Society.pdf. Accessed 24 Aug. 2020.

Santos, Mateus Renno, and Alexander Testa. »Homicide is declining around the world but why? « The Conversation, 2019, https://theconversation.com/homicide-is-declining-around-the-world-but-why-125365. Accessed 21 Aug. 2020.

Sinding Bentzen, Jeanet. »In Crisis, We Pray: Religiosity and the COVID-19 Pandemic.« University of Copenhagen, 2020, https://www.economics.ku.dk/research/corona/ Bentzen_religiosity_covid.pdf. Accessed 21 Aug. 2020.

Šonje, Velimir. »Koronaekonomika (II): pet jahača apokalipse i može li 'Savjet' pomoći?« Ekonomski Lab, 2020, http://arhivanalitika.hr/blog/koronaekonomika-ii-pet-jahaca-apokalipse-i-moze-li-savjet-pomoci/. Accessed 26 Aug. 2020.

Takieddine, Hiba, and Samaa Al Tabbah. »Coronavirus Pandemic: Coping with the Psychological Outcomes, Mental Changes, and the 'New Normal' During and After COVID-19.« Open Journal of Depression and Anxiety 2020, pp. 7-19.

Taubenberger, Jeffery. »The Origin and Virulence of the 1918 'Spanish' Influenza Virus.« American Philosophical Society, vol. 150, no. 1, 2006, pp. 86-112.

Thurow, Lester. Budućnost kapitalizma - kako današnje gospodarske snage oblikuju sutrašnji svijet, Zagreb: Biblioteka Gospodarska misao, 1997.

United Nations $(=\mathrm{UN}), \gg 5$ reasons the world needs WHO, to fight the COVID-19 pandemic. $\ll$ UN News, 2020, https://news.un.org/en/story/2020/04/1061412. Accessed 27 Aug. 2020.

---, »The COVID-19 shadow pandemic: Domestic violence in the world of work: A call to action for the private sector.«UN Women, 2020, https://www.unwomen.org/-/media/ headquarters/attachments/sections/library/publications/2020/brief-covid-19-domestic-violence-in-the-world-of-work-en.pdf?la=en\&vs=5715. Accessed 21 Aug. 2020.

Wagner, Livia, and Thi Hoang. »Aggravating Circumstances - How coronavirus impacts human trafficking.« Global Initiative, 2020, https://globalinitiative.net/wp-content/ uploads/2020/06/Aggravating-circumstances-How-coronavirus-impacts-human-trafficking-GITOC-1.pdf. Accessed 21 Aug. 2020.

Walker, Summer. »Covid-19 and Crime - A response develops at the UN.« Global Initiative, 2020, https://globalinitiative.net/wp-content/uploads/2020/06/Covid-19-andcrime-A-response-develops-at-the-UN.pdf. Accessed 21 Aug. 2020. 
Wang, James, and Bill Chameides. »Are Humans Responsible for Global Warming? « Environmental Defense, 2007, https://www.edf.org/sites/default/files/5279_GlobalwarmingAttributuion.pdf. Accessed 21 Aug. 2020.

Wood, Sylvia, and Andréa Ventimiglia. »Global Fires. « Future Earth, 2020, https://futureearth.org/publications/issue-briefs-2/global-fires/. Accessed 22 Aug. 2020.

World Health Organization (=WHO), »Constitution of the World Health Organization.« 2006, https://www.who.int/governance/eb/who_constitution_en.pdf. Accessed 27 Aug. 2020.

---, >Coronavirus disease 2019 (COVID-19) Situation Report - 46.« https://www.who. int/docs/default-source/coronaviruse/situation-reports/20200306-sitrep-46-covid-19.pdf?sfvrsn=96b04adf_4. Accessed 19 Aug. 2020.

---, »Coronavirus disease 2019 (COVID-19) Situation Report - 94.« https://www.who. int/docs/default-source/coronaviruse/situation-reports/20200423-sitrep-94-covid-19.pdf?sfvrsn=b8304bf0_4. Accessed 21 Aug. 2020.

World Trade Organization (=WTO), E-commerce, $\gg$ E-commerce, Trade and the COVID-19 Pandemic.« 2020, https://www.wto.org/english/tratop_e/covid19_e/ecommerce_report_e.pdf. Accessed 24 Aug. 2020.

Zuckerman, Phil. Society without God: What the Least Religious Nations Can Tell Us About Contentment, New York: NYU Press, 2010. 


\title{
LAUDATO SI' - SOCIOEKONOMSKA RELEVANTNOST ZA DINAMIČNU, PROMJENJIVU I IZAZOVNU BUDUĆNOST
}

\author{
Richard PAVLIĆ* - Bruno RUKAVINA**
}

Sažetak: Rad se bavi relevantnošću enciklike Laudato si' pet godina nakon njezina objavljivanja. S obzirom na koronakrizu, koja je pokretač nove ekonomske krize u svijetu, vjerujemo da je enciklika Laudato si' relevantnija u 2020. godini nego 2015. godine. Rad analizira tri socioekonomska segmenta enciklike Laudato si' kako bi se prikazala njezina važnost danas: čovječanstvo i naš odnos s drugim ljudima, Bogom i okolišem, nova kriza u gospodarstvu i nužnost globalne akcije za razumijevanje i prevladavanje koronakrize. Procesi i opasnosti od prije pet godina nisu nestali, nego su samo promijenili oblik. Dakle enciklika Laudato si' nije samo relevantna već se njome može koristiti i kao programom socioekonomske obnove za posljedice koronakrize.

Ključne riječi: papa Franjo, Laudato si', koronakriza, koronavirus, zaključavanje, ekonomski sustav, ekonomska kriza, tehnologija, antropocentrizam.

* Doc. dr. sc. Richard Pavlić, Katolički bogoslovni fakultet Sveučilišta u Zagrebu, Teologija u Rijeci Područni studij Katoličkoga bogoslovnog fakulteta Sveučilišta u Zagrebu, Omladinska 14, 51000 Rijeka, Hrvatska, ripavlic@gmail.com

** Bruno Rukavina, mag. polit., Hrvatska, bruno.rukavina.fpzg@gmail.com 